Acker,W., Parkinson,J., Mabote,M., Campos,L.C. (2016) Assessing health risks associated with municipal sanitation systems in Maputo, Mozambique. Waterlines, 35(4):397-411.

\title{
Assessing health risks associated with municipal sanitation systems in Maputo, Mozambique
}

\author{
Authors: \\ William Acker \\ University College London, UK \\ Jonathan Parkinson \\ Oxfam, UK \\ Moises Mabote \\ Class-A, Mozambique \\ Luiza C. Campos \\ University College London, UK
}

\begin{abstract}
The aim of this study was to pilot a practical methodology to assess the condition of sanitation infrastructure and faecal sludge management (FSM) services in order to understand the relative magnitude of the associated environmental health risks. This risk assessment tool was developed as part of the Participatory Rapid Sanitation System Risk Assessment (PRSSRA) methodology which uses local stakeholder knowledge to assess the risks in sanitation chains in order to prioritise interventions to reduce these risks. The tool described in this paper focuses on municipal level sanitary infrastructure which complements the community level risk assessment.

The study's methodology determines the extent of sewerage infrastructure and FSM services, what condition these systems are in and how they are managed. Through a system of scoring according to criteria that are attributed to health risks, it identifies key weaknesses in the system and critical points where health risks are concentrated. The approach is then used to prioritise the need for interventions and make recommendations for improvement. The paper compares the methodology being piloted against two other approaches that have been developed to assess faecal contamination in low-income settings: SaniPath and Shit Flow Diagram. This study discusses the merit of using this methodology as a standalone tool and including it into SaniPath and SFD in its current or a modified form.
\end{abstract}

Key words: Sanitary surveying, risk assessment, participatory research, urban sanitation 


\section{Introduction}

Population growth and poor maintenance and management have rendered urban sanitation services inadequate in most cities in the developing world. This leads to residential areas being contaminated with untreated human excreta and proliferation of sanitation-related diseases. Conventional methods for assessing the condition of sanitation services and the level of health risk are data intensive, expensive, time consuming and impractical in unplanned settlement contexts, making them unsuitable for cities in Sub-Saharan Africa.

The risk assessment framework developed under the project provides a comprehensive and systematic assessment of sanitation related risks using a structured framework of indicators that take into account a wider range of factors that are not normally considered during planning processes. The Participatory Rapid Sanitation System Risk Assessment (PRSSRA) methodology (Campos et al. 2015) uses local stakeholder knowledge as part of a participatory and rapid risk assessment methodology that assesses the risks in sanitation chains in order to prioritise interventions to reduce these risks.

The PRSSRA methodology focuses on an assessment of sanitation risks at two levels:

1) Municipal level: The methodology considers systems for collection and disposal of human excreta. Risk is calculated according to the hazardous events that occur at specific points in the sanitation chain rather than according to geographical as in the case of the community level assessment.

2) Community level: the community level risk assessment is a participatory process which gauges risks associated with inadequate sanitation facilities, a lack of servicing of these facilities and poor local level infrastructure for waste collection that results in hazards prevalent in the local environment.

This paper focuses on the former part of the assessment i.e. the risk assessment tool for municipal infrastructure.

\section{Overview of municipal level risk assessment}

This study proposes a low-cost and rapid methodology for assessing sanitation associated health risks that is based on participatory research methods, transect walks, key informant interviews (KIls) and risk assessment estimations. The methodology does not require any lab work. The methodology assesses the performance, condition and management of the sanitation infrastructure and FSM service to estimate health risk, which is characterized according to the principal hazardous events occurring as result of poor sanitation infrastructure and FSM service provision. 
The methodology is aimed at prioritising investments and recommending improvements in sanitation infrastructure and FSM. It estimates health risk for each of the hazardous events that occur as a result of failures of the sanitation infrastructure and FSM service. The sanitary survey component shows what about the system or its context is causing the hazardous events and therefore what improvements would result in the greatest reduction of health risk.

The focus on sanitation infrastructure and FSM services means this methodology does not capture information about faecal contamination situations that occur in the absence of any sanitation service such as open defecation, pit abandonment and manual pit emptying. Assessment of these risks is covered by the complementary community level risk assessment described in Campos et al. (2015).

The municipal level risk assessment (Figure 1) is made up of four steps:

1) Mapping

2) Definition of hazardous events

3) Sanitary surveys

4) Risk assessment

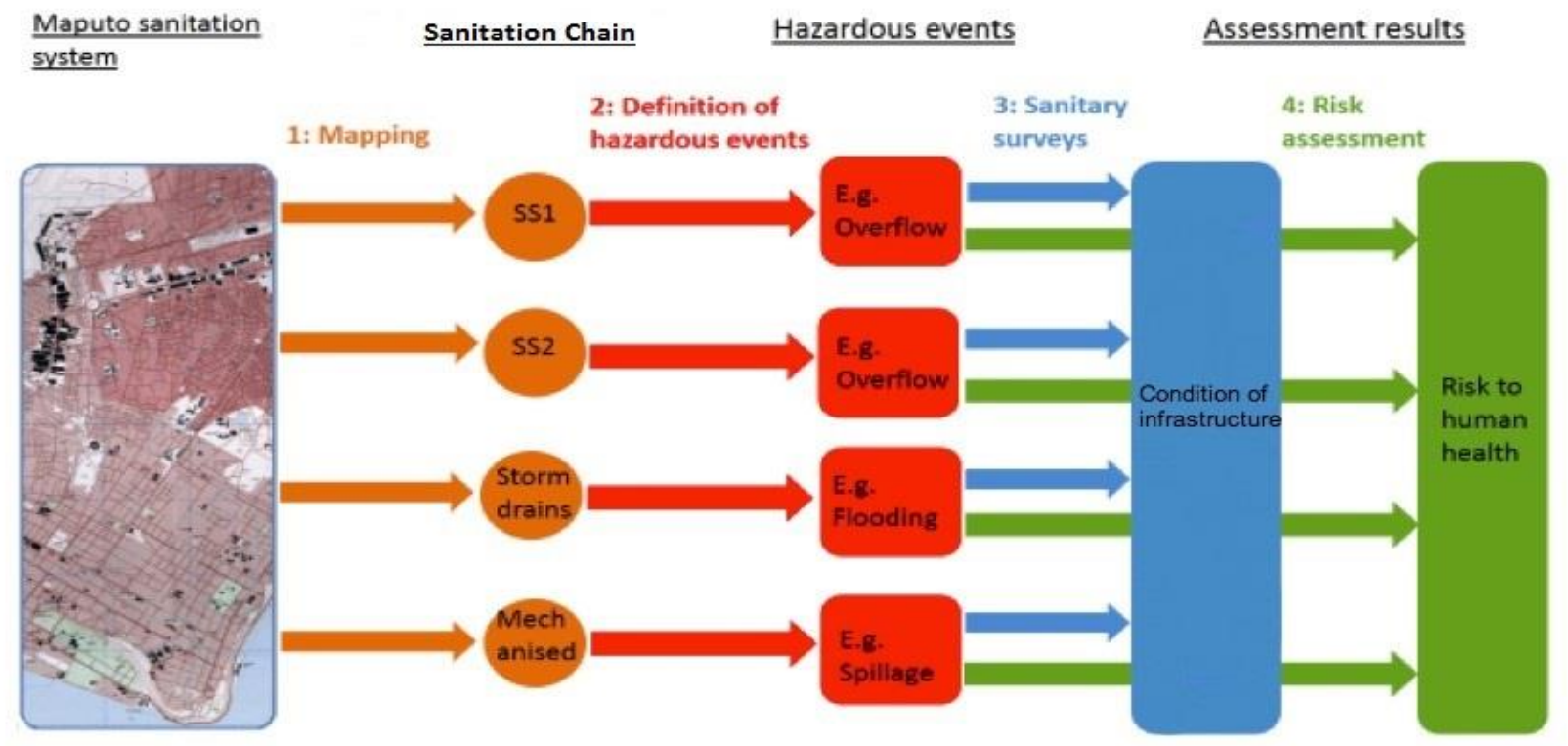

Figure 1 Four steps of methodology (SS = Sewer system). Note: SS1 = sewer system $1 ;$ SS2 = sewer system 2.

Step 1 - Mapping stage: to determine what sanitation infrastructure and FSM service is present in the city.

Step 2 - Definition of hazardous events: a participatory process carried out with technicians and operators of sanitation infrastructure or FSM services in order to produce a table of principal hazardous events. 
Step 3 - Sanitary survey: developed with stakeholders for each hazardous event. They are concise list of questions that qualitatively assess the likelihood of the hazardous event occurring as a result of the condition or management of the sanitation infrastructure or FSM equipment.

Step 4: The risk assessment is performed separately for each hazardous event using ranked responses for hazard intensity and frequency, number of people affected and the age and social class of people affected. It estimates the magnitude of health risks caused by different hazards events.

All data collection involving civil servants, private service providers and community level stakeholders was done after explaining the purpose of this study and receiving their consent that information they gave could be used.

\section{Details of methodology}

\section{Step 1 - Mapping}

The objective of the mapping exercise was to understand what sanitation infrastructure and FSM services are present. The study area was the city of Maputo, not including peri-urban sprawl. Literature review, participatory research methods, transect walks and site visits were used to map the sanitation infrastructure and FSM services. Four different sanitation chains were identified according to the different conveyance methods (Figure 1):

1. Sewer system 1 (SS1)

2. Sewer system 2 (SS2)

3. Faecal sludge management (i.e. Mechanised)

4. Storm drains

The pathways of these sanitation chains identified two other key sanitation infrastructure elements:

5. Waste stabilisation ponds (WSPs)

6. Peri-urban farming areas

Due to time constraints, the storm drains and the implications of disposal of waste in Maputo Bay were not investigated in this study. Figure 2 summarises the findings of the mapping exercise. 


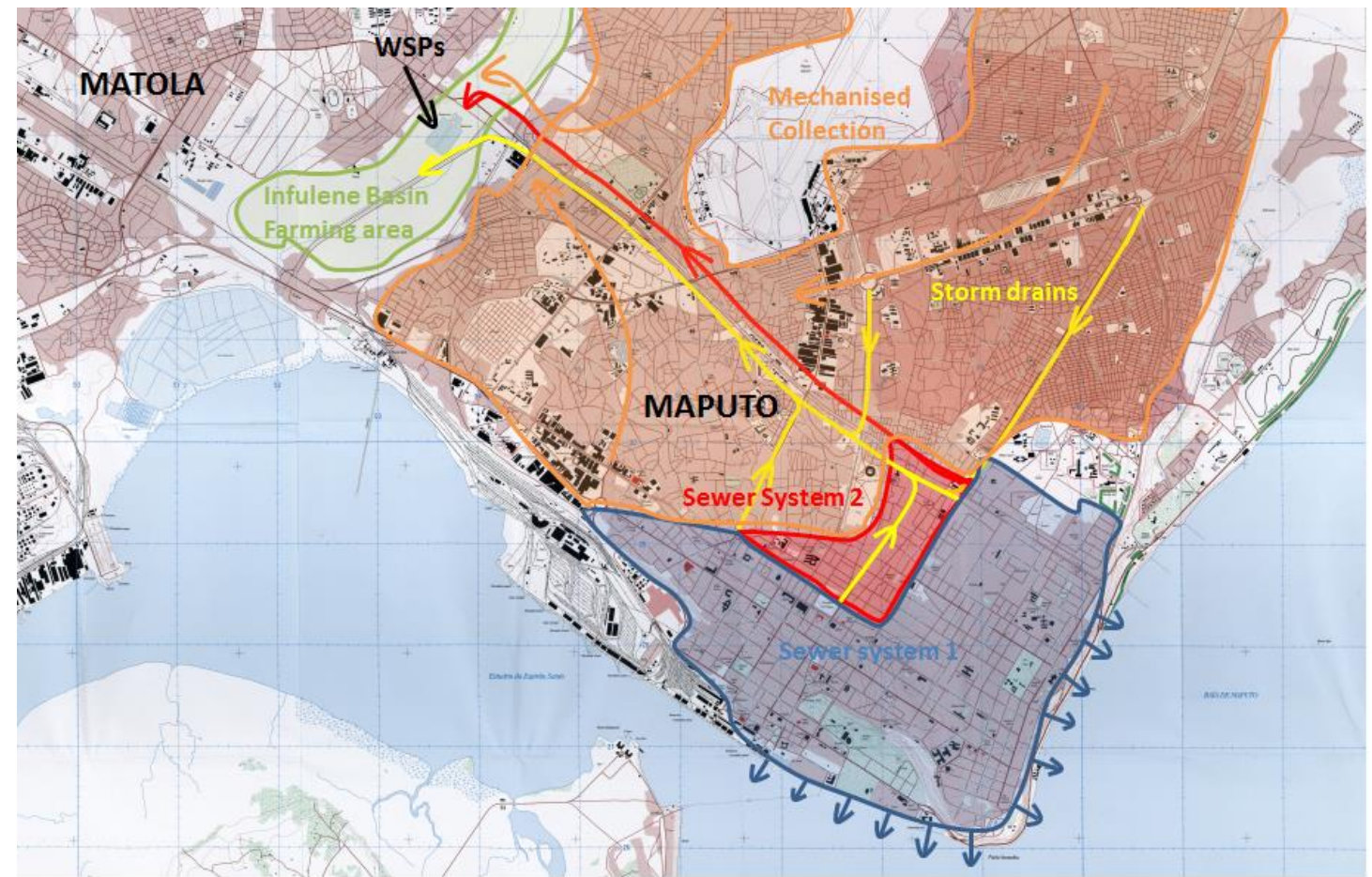

\section{Figure 2 Summary of mapping exercise}

The sanitation service chains were split into 3 phases: i) transport, ii) treatment, and iii) reuse/disposal. Figure 3 shows the different pathways that excreta can take from where it is produced to an area of treatment, reuse or leaving the city.

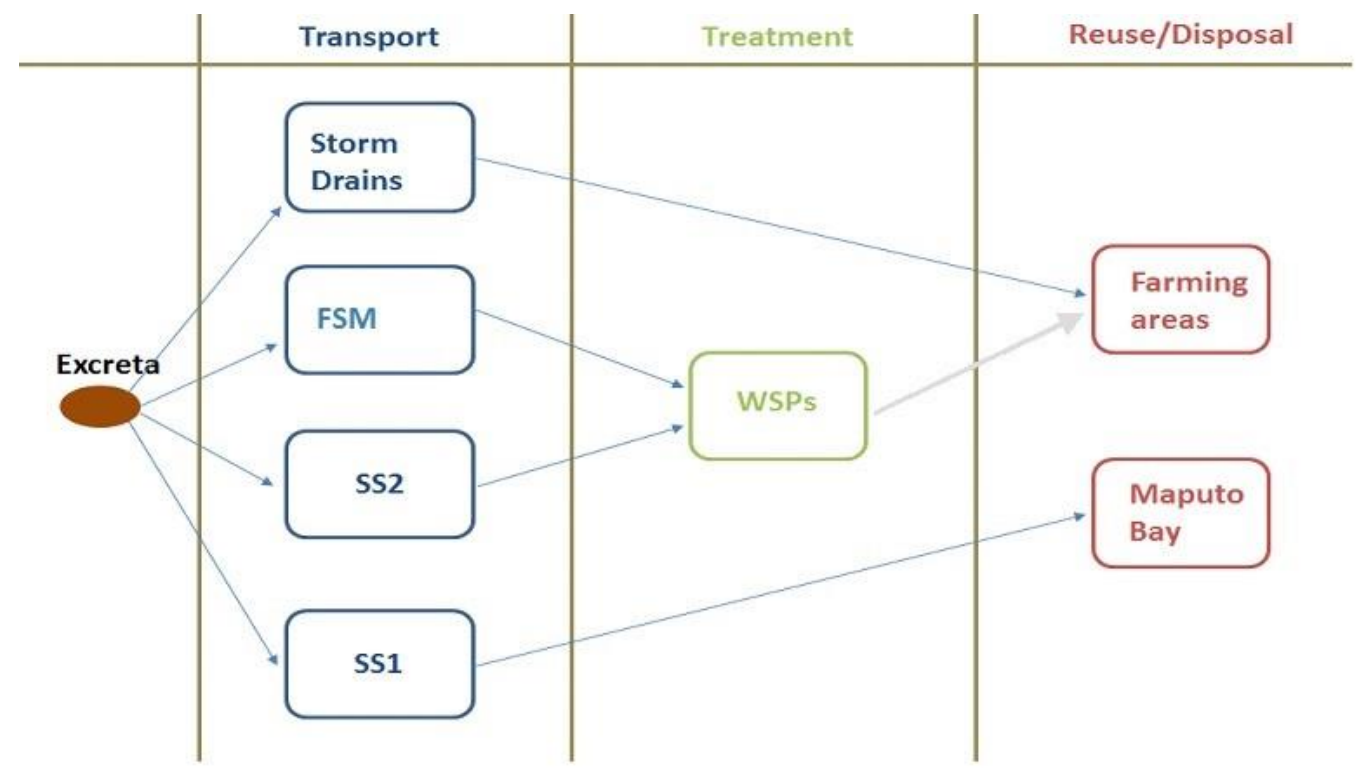

Figure 3 Phases of Maputo's sanitation infrastructure and FSM services 


\section{Step 2 - Definition of hazardous events}

A hazardous event definition form that summarized the assessor's understanding of the different sanitation chains and associated hazardous events was reviewed with stakeholders to produce a verified list of principal hazardous events for each sanitation chain. Figure 4 shows the hazard definition form for faecal sludge management. The assessor's understanding of sanitation chain and risks is normal script, stakeholder input is in bold.

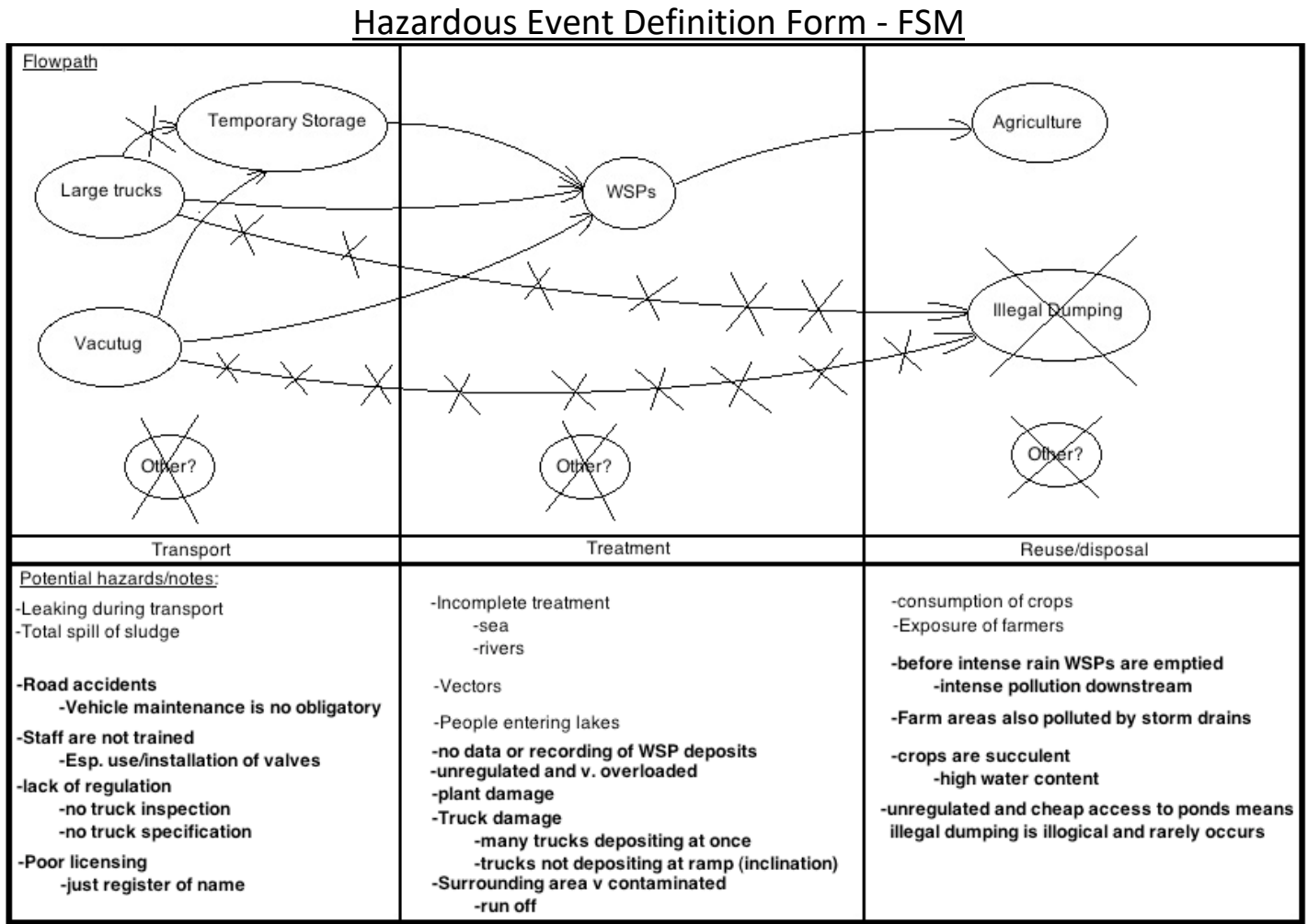

Figure 4 - Hazard definition form used for the (FSM) mechanised sanitation chain

Table 1 shows the stakeholder verified table of principal hazardous events for the Maputo area. 
Table 1 - Table of principal hazardous events for the Maputo area

\begin{tabular}{|c|c|c|c|}
\hline \multirow{2}{*}{$\begin{array}{l}\text { Sanitation } \\
\text { Chain }\end{array}$} & \multicolumn{3}{|l|}{ Sanitation Phase } \\
\hline & Transport & Treatment & Reuse/disposal \\
\hline \multirow[t]{2}{*}{ Mechanised } & \multirow{2}{*}{$\begin{array}{l}\text { No hazardous } \\
\text { events }\end{array}$} & $\begin{array}{l}\text { People } \\
\text { entering } \\
\text { WSPs }\end{array}$ & $\begin{array}{l}\text { Downstream } \\
\text { agriculture }\end{array}$ \\
\hline & & WSP flood & $\begin{array}{l}\text { Consumers } \\
\text { produce }\end{array}$ \\
\hline \multirow[b]{2}{*}{ SS1 } & Overflow & \multirow{2}{*}{$\begin{array}{l}\text { No } \\
\text { treatment }\end{array}$} & \multirow{2}{*}{$\begin{array}{l}\text { No ha } \\
\text { events }\end{array}$} \\
\hline & $\begin{array}{l}\text { Cross- } \\
\text { contamination }\end{array}$ & & \\
\hline \multirow{3}{*}{ SS2 } & $\begin{array}{l}\text { Storm water } \\
\text { overflow }\end{array}$ & \multirow{2}{*}{$\begin{array}{l}\text { People } \\
\text { entering } \\
\text { WSPs }\end{array}$} & \multirow{2}{*}{$\begin{array}{l}\text { Downstream } \\
\text { agriculture }\end{array}$} \\
\hline & $\begin{array}{l}\text { Wastewater } \\
\text { overflow }\end{array}$ & & \\
\hline & $\begin{array}{l}\text { Cross- } \\
\text { contamination }\end{array}$ & WSP flood & $\begin{array}{l}\text { Consumers } \\
\text { produce }\end{array}$ \\
\hline
\end{tabular}

\section{Step 3 - Sanitary survey forms}

A sanitary survey form was developed for each hazardous event to qualitatively assess how likely it is to occur and for what reason. Each has two parts:

- System trigger mechanisms: Characteristics of the system itself that can cause the hazardous event to occur, e.g. are the sewage pipes fit for use?

- Context trigger mechanisms: Characteristics of the system's context that can cause the hazardous event to occur, e.g. do sewer maintenance and repairs teams have appropriate equipment?

Survey development is a three stage participatory process (see figure 5) that involves stakeholder interview, guided site visits and iterative refinement.

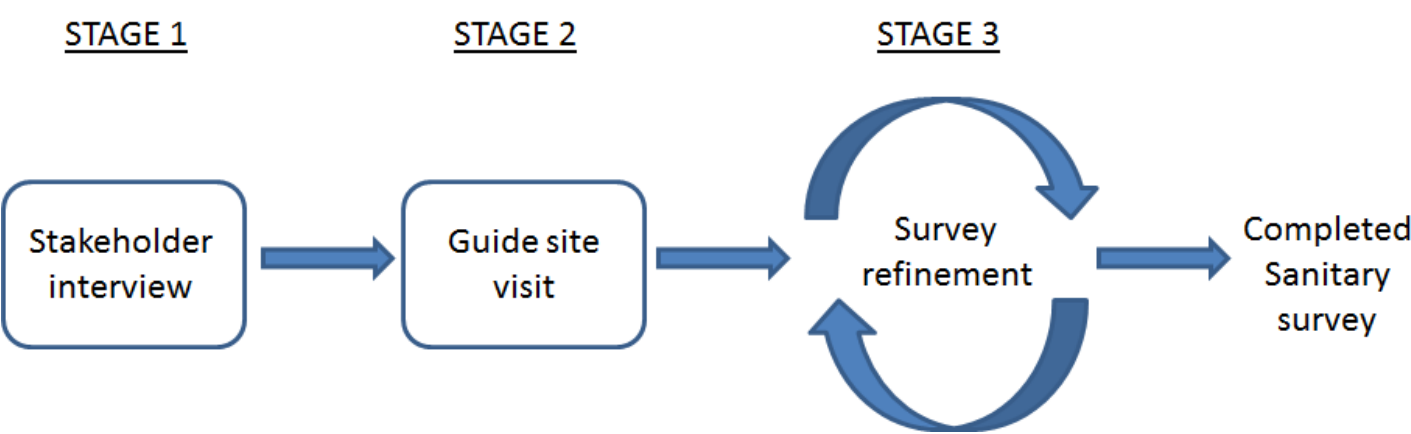

Figure 5 - Three stage process of sanitary survey development

Each trigger mechanism is analysed by a question with three responses: a good, normal and bad scenario (0, 1 and 2 points, respectively). Scores are calculated as a percentage of maximum. The higher the score, the poorer the assessment. A separate score was calculated for the hazardous events' system and context trigger mechanisms. 
Table 2 - Sanitary survey form for the 'SS1 Overflow' hazard system trigger mechanism

\begin{tabular}{|c|c|c|c|c|}
\hline \multirow[b]{2}{*}{ Hazard Mechanism } & \multicolumn{4}{|c|}{ Response scenario and scoring } \\
\hline & $\begin{array}{c}\text { Good } \\
0 \text { points }\end{array}$ & $\begin{array}{l}\text { Normal } \\
1 \text { point }\end{array}$ & $\begin{array}{c}\text { Bad } \\
2 \text { points }\end{array}$ & Notes \\
\hline $\begin{array}{l}\text { Check } 3 \text { inspection boxes. Is there a } \\
\text { build-up of rubbish? }\end{array}$ & No & To some extent & A lot & Municipal waste collection is a major issue \\
\hline $\begin{array}{l}\text { Check } 3 \text { flood retention boxes. Is } \\
\text { there a build-up of solid material? }\end{array}$ & No & To some extent & A lot & $\begin{array}{l}\text { There is no routine emptying of the flood } \\
\text { retention boxes and they are designed for } \\
\text { easy inflow }\end{array}$ \\
\hline $\begin{array}{l}\text { Check } 3 \text { inspection boxes. Is there an } \\
\text { excessive accumulation of solids in } \\
\text { the open pipe (see appendix } 2 \text { )? }\end{array}$ & No & To some extent & Yes & $\begin{array}{l}\text { This is particularly bad at time of } \\
\text { measurement (dry season) and in 'Baixa' } \\
\text { area due to lack of incline. }\end{array}$ \\
\hline $\begin{array}{l}\text { Do blockages commonly occur due } \\
\text { to deposition of kitchen/mechanical } \\
\text { oils? }\end{array}$ & No & Sometimes & Often & $\begin{array}{l}\text { SS1 covers central part of town with many } \\
\text { restaurants and mechanics. There is a lack of } \\
\text { awareness regarding this issue. }\end{array}$ \\
\hline Are the pipes fit for purpose? & Yes & Most & Few & $\begin{array}{l}\text { Concrete pipes from the } 1940 \text { s are being } \\
\text { replaced with PVC }\end{array}$ \\
\hline Points & \multicolumn{4}{|l|}{ Score } \\
\hline $10 / 10$ & \multicolumn{4}{|l|}{100} \\
\hline
\end{tabular}


A completed sanitary survey integrates information from a range of stakeholders/sources, identifies the key problems and lists potential causes/interventions.

\section{Step 4 - Risk assessment}

The risk to human health presented by each hazardous event was calculated based on Crichton's risk triangle (Crichton, 1999):

Risk score = Hazard Intensity $x$ Exposure $x$ Vulnerability

This was modified to:

Risk score $=$ Hazard intensity $x$ (Frequency of Event + Number of People Exposed) $x$ (Age + Social Class)

\section{Hazard Intensity:}

The waste fluids that cause the hazardous events in this study were ordered according to their pathogen load. Faecal Coliform Count (FCC) was used to rank the different waste fluids according to hazard intensity (Table 3 ). Where numerous fluids were present the intensity was taken as an average. Where a process of pathogen die-off or dilution occurred, the intensity was reduced by one.

Table 3 - FCC and ranking of different waste fluids

\begin{tabular}{lccccc}
\hline Hazard type & $\begin{array}{c}\text { Contaminated } \\
\text { run-off }\end{array}$ & $\begin{array}{c}\text { Septic tank } \\
\text { discharge }\end{array}$ & $\begin{array}{c}\text { Raw } \\
\text { sewage }\end{array}$ & $\begin{array}{c}\text { Faecal } \\
\text { sludge }\end{array}$ & $\begin{array}{c}\text { Open } \\
\text { defecation }\end{array}$ \\
\hline $\begin{array}{l}\text { FCC (count per } \\
100 \mathrm{ml})\end{array}$ & $50-10^{5}$ & $10^{3}-10^{6}$ & $10^{8}-10^{9}$ & $10^{8}-10^{10}$ & $10^{11}$ \\
& $\begin{array}{c}\text { Geldreich et al, } \\
1968\end{array}$ & $\begin{array}{c}\text { Horsley } \\
\text { \&Witten, } 1996\end{array}$ & EPA, 1980 & Ashbolt \& Snozzi, 2001 \\
\hline $\begin{array}{l}\text { Hazard intensity } \\
\text { ranking }\end{array}$ & 1 & 2 & 3 & 4 & 5 \\
\hline
\end{tabular}

Frequency of Events:

Frequency of event data was collected from stakeholders and ranking is shown in Table 4.

Table 4 - Hazard frequency ranking

\begin{tabular}{cccccc}
\hline Rank & 1 & 2 & 3 & 4 & 5 \\
\hline $\begin{array}{c}\text { Frequency of } \\
\text { event }\end{array}$ & $\begin{array}{c}\text { Less than } \\
\text { once a year }\end{array}$ & Yearly & Monthly & Weekly & Daily or more \\
\hline
\end{tabular}


Number of People Exposed:

Number of people exposed data was collected from community level stakeholders and staff involved with service provision (Table 5).

Table 5 - Number of people exposed per event ranking

\begin{tabular}{|c|c|c|c|c|c|}
\hline Rank & 1 & 2 & 3 & 4 & 5 \\
\hline $\begin{array}{l}\text { Number of } \\
\text { People } \\
\text { Exposed }\end{array}$ & 100 or less & $100-1000$ & $1000-10,000$ & $\begin{array}{l}10,000- \\
100,000\end{array}$ & $\begin{array}{c}100,000 \text { or } \\
\text { more }\end{array}$ \\
\hline
\end{tabular}

Vulnerability (Age and Social class):

Age and social class were used as proxy indicators for vulnerability to disease (Tables 6 and 7). Data was collected from community level stakeholders and staff involved with service provision.

Table 6 - Age ranking

\begin{tabular}{lccc}
\hline Rank & 1 & 2.5 & 5 \\
\hline Age & Adults & Mixed & Children \\
\hline
\end{tabular}

Table 7 - Social class ranking

\begin{tabular}{lccc}
\hline Rank & 1 & 2.5 & 5 \\
\hline Social Class & $\begin{array}{c}\text { Middle class } \\
\text { and up }\end{array}$ & Mixed & Poor \\
\hline
\end{tabular}

Table 8, below, shows the full risk assessment table and data collected for the crosscontamination hazard. 
Table 8 - Risk assessment table for the 'Cross-contamination' hazard

\begin{tabular}{|c|c|c|c|c|c|c|c|}
\hline Hazardous event & & & Rank & & & & \\
\hline $\begin{array}{l}\text { Cross- } \\
\text { contamination }\end{array}$ & 1 & 2 & 3 & 4 & 5 & $\begin{array}{l}\text { Data } \\
\text { point }\end{array}$ & Notes \\
\hline Hazard Intensity & $\begin{array}{l}\text { Contamina } \\
\text { ted run-off }\end{array}$ & $\begin{array}{l}\text { Septic tank } \\
\text { discharge }\end{array}$ & $\begin{array}{l}\text { Raw } \\
\text { sewage }\end{array}$ & $\begin{array}{l}\text { Faecal } \\
\text { sludge }\end{array}$ & $\begin{array}{c}\text { Open } \\
\text { defecation }\end{array}$ & 1.5 & $\begin{array}{l}\text { Occurs from both SS1 and SS2 } \\
\text { pipes and is diluted. }\end{array}$ \\
\hline Frequency of Events & $\begin{array}{l}\text { Less than } \\
\text { once a } \\
\text { year }\end{array}$ & Yearly & Monthly & Weekly & $\begin{array}{l}\text { Daily or } \\
\text { more }\end{array}$ & 5 & $\begin{array}{l}\text { Drinking water pipes lose +ve } \\
\text { pressure daily }\end{array}$ \\
\hline \multirow[t]{3}{*}{$\begin{array}{l}\text { Number of People } \\
\text { Exposed }\end{array}$} & $\begin{array}{l}\text { Less than } \\
\qquad 100\end{array}$ & $100-1000$ & $\begin{array}{l}1000- \\
10,000\end{array}$ & $\begin{array}{l}10,000- \\
100,000\end{array}$ & $\begin{array}{l}\text { More than } \\
100,000\end{array}$ & 5 & $\begin{array}{l}\text { The city centre that receives piped } \\
\text { water has over 200,000 people } \\
\text { living there }\end{array}$ \\
\hline & & Rank & & & & & \\
\hline & 1 & 2.5 & 5 & & & & \\
\hline Age & Adults & Mixed & Children & $\mathrm{n} / \mathrm{a}$ & $\mathrm{n} / \mathrm{a}$ & 2.5 & Households made up of families \\
\hline Social Class & $\begin{array}{l}\text { Middle } \\
\text { class and } \\
\quad \text { up }\end{array}$ & Mixed & Poor & $\mathrm{n} / \mathrm{a}$ & $\mathrm{n} / \mathrm{a}$ & 1 & $\begin{array}{l}\text { Only the richest people have } \\
\text { pumped water }\end{array}$ \\
\hline
\end{tabular}




\section{Results of the risk assessment and recommended interventions}

\subsection{Risk assessment}

Table 9 shows the sanitary survey scores for each hazardous event. System is abbreviated to ' $\mathrm{S}$ ' and context is abbreviated to ' $\mathrm{C}$ '.

Table 2 - Sanitary survey results

\begin{tabular}{lcc}
\hline Hazardous Event & System Score (S) & Context Score (C) \\
\hline SS1 overflow & 100 & 67 \\
\hline SS2 wastewater overflow & 90 & 58 \\
\hline SS2 stormwater overflow & 70 & 58 \\
\hline Cross-contamination & 70 & 60 \\
\hline People entering WSPs & 100 & 90 \\
\hline Flooding of the WSPs & 80 & 90 \\
\hline Downstream agriculture activities & 100 & 80 \\
\hline Consumers of produce & 90 & 80 \\
\hline Average score & $\mathbf{8 7 . 5}$ & $\mathbf{7 4 . 5}$ \\
\hline
\end{tabular}

The results (Table 9) indicate a very poor condition of the sanitation infrastructure and FSM equipment and its surrounding context. Average scores of the system (87.5) and context (74.4) surveys indicate that it is the condition of the sanitation infrastructure and FSM equipment itself rather than the context that causes most hazardous events to occur. The 'People Entering the WSPs' (100), 'SS1 WW Overflow' (100) and 'Downstream Agriculture' (100) hazards pose the greatest risk to human health.

The bars in Figure 6 shows every hazardous event's individual risk factor and the System and Context sanitary survey scores are indicated by the numbers followed by ' $S$ ' and ' $C$ ', respectively. Risk scores are colour coded according to lower, middle and upper quartiles. The sanitary survey scores and associated information allow the reader to understand why a particular hazard is occurring and what can be done to lower the risk to human health. 


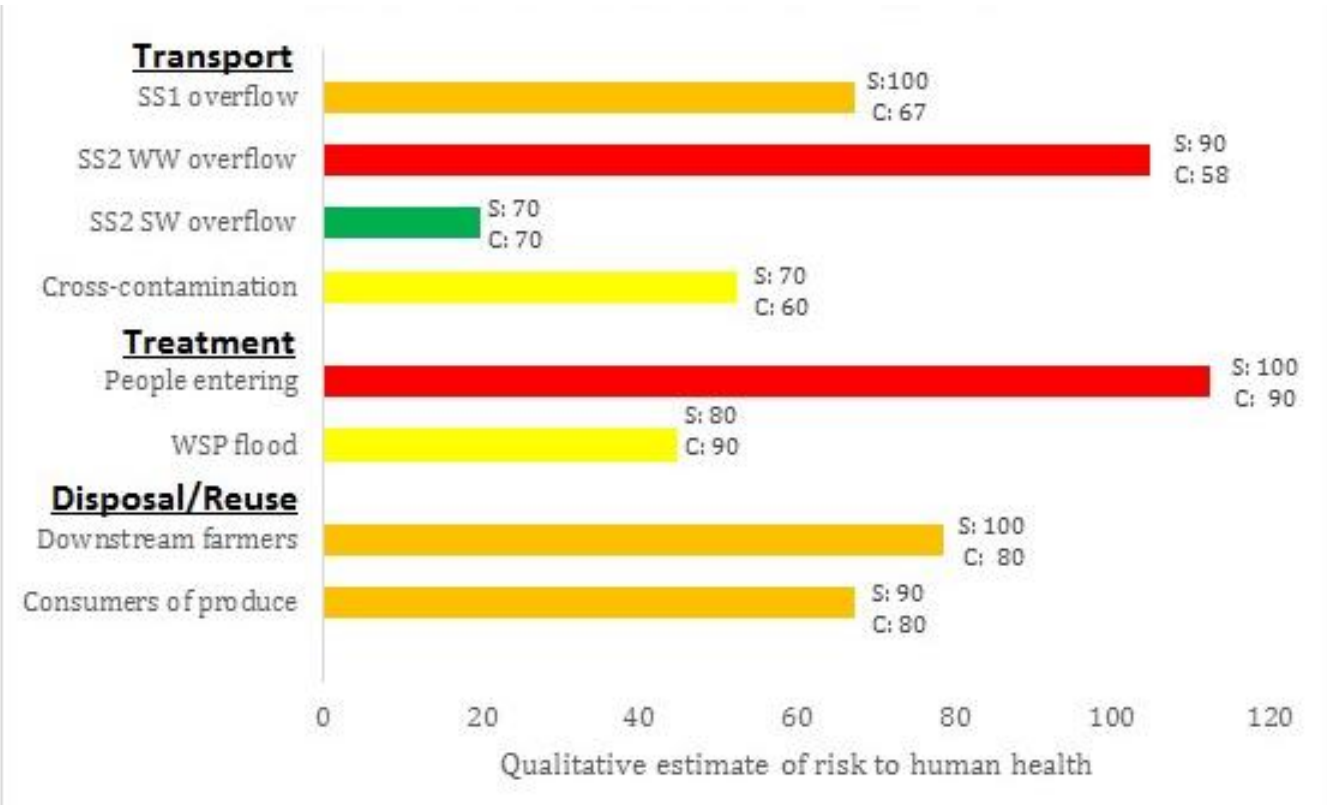

Figure 6 - Dual presentation of risk assessment and sanitary survey results. Note: $\mathbf{W W}=$ wastewater; $\mathbf{S W}=$ stormwater; $\mathbf{W S P}=$ waste stabilization pond, $\mathbf{S}=$ system, $C=$ context

The transport phase presents the most risk, despite scoring best in the condition of the SS2 SW overflow (70), due to the frequency of hazardous events compared with the other phases. This is logical as it occurs in the city centre, the area of deposition of human waste and where the majority of the city's population circulates.

The treatment phase had the highest average level of risk per event. This is due to the high risk score for the 'People Entering the WSPs' (100). Sanitary surveys showed that the WSPs are in terrible condition.

The disposal/reuse phase presents the least risk. This was expected, as it is the furthest from waste deposition and after treatment/natural pathogen die-off. However, it still reached a greater level of average risk per hazard than the transport phase. This is due to the high frequency of the events, the large number of consumers of contaminated produce, and the poverty of the farmers handling contaminated water. 
Table 10 shows, for each phase, the data collected for hazardous events and the risk scores that were calculated.

Table 3 - Summary table of risk assessment results

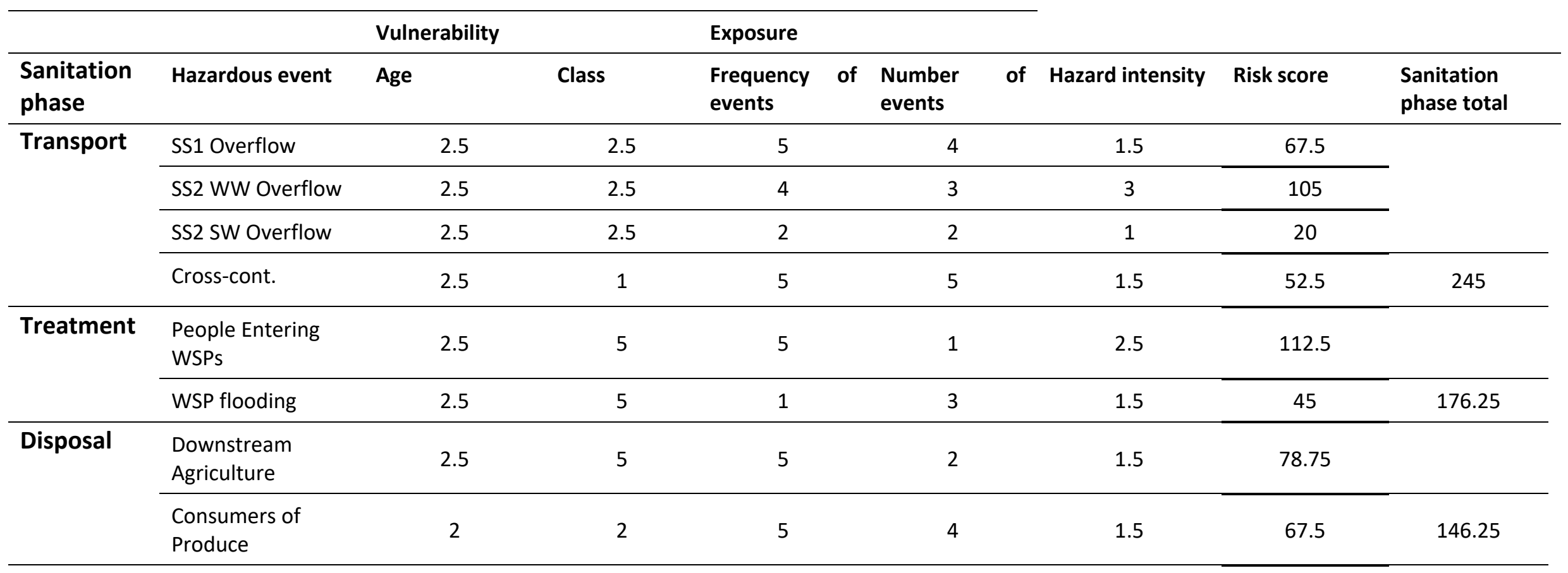


The results of the sanitary surveys appear to accurately represent the reality in Maputo. Previous academic and municipal reviews (Muximpua \& Hawkins, 2012)(WSUP, 2010)(Godfrey, 2012)(Lahmeyer, 2004)(IWA 2011, 2015) frequently mention the top five most hazardous events and many of the hazard system and context mechanisms highlighted in this study.

\subsection{Recommended interventions}

\section{Low cost recommendations:}

Providing fencing and security would prevent the highest risk hazardous event, 'People entering the WSPs', from occurring. This would reduce the city's total risk score from 567.5 to 455 , a reduction of $19.8 \%$. Providing an alternative water source for the farmers to prevent the use of contaminated water for irrigation would eliminate the 'Downstream Agriculture' and the 'Consumers of Produce' hazards. This results in a risk reduction of $146,25.7 \%$ of the total. Combined, both interventions reduce risk by $258.7,45.6 \%$ of the total, and would not require huge expenditure.

\section{High cost recommendations:}

The most relevant interventions, according to the information collected by sanitary surveys, are:

- Improvement of the municipal solid waste collection and removal of sand and debris from the streets

- Enlargement of pipes

- Purchase of pipe inspection equipment.

- Fat/oil/grease collection.

Prevention of the transport phase's hazardous events would result in a reduction of total city risk of 245 , a percentage improvement of $43 \%$. However, these would require significant sanitation infrastructure works and FSM service improvements, which would be costly and may not result in the total prevention of the hazards.

\section{Discussion and comparison with other methodologies}

The SaniPath (Emory University, 2014) and Shit-Flow Diagrams (SFD promotion initiative, 2015) provide rapid, low cost methodologies that are already being used to gather information about sanitation service in low-income settings. Our approach is complementary to these risk assessment methodologies as it uses similar research methods to gather data with the aim to produce an overview of the situation that can be used to inform policy and prioritise interventions. This section provides a comparison; highlighting some of the strengths and weaknesses of these different approaches.

The SFD approach provides a city wide overview of the risk of faecal contamination in a low-income context. It yields an understanding of the different sanitation and FSM systems present, percentage usage, efficacy and overall service delivery context, including regulation, legislation etc. The sanitary survey component of this 
methodology could be useful as a sub-element of the SFD approach to provide an indepth assessment of an element of the sanitation infrastructure or FSM service. It could be used to focus in on this element, identify the key problems with its performance, management and condition and would have a lot of value as a tool to prioritise interventions and investments into this particular element.

The most useful aspect of this methodology was the sanitary survey component's ability to focus in on a particular element of the sanitation infrastructure and FSM service and yield context specific information about how it is performing, how it is managed, what condition it is in and what can be done to improve it. The approach described above is able to do this in a way that neither SaniPath nor SFD are able to because it is not constrained by a list of pre-determined questions and uses a participatory approach to reveal information that might not fit into a one-size-fits-all set of questions.

The SaniPath approach with its focus on community behaviour, exposure pathways and CFU E. coli provides an assessment of risk to human health but is not used to recommend interventions that would be most effective at reducing health risk as its approach is not context specific. The PRSSRA methodology has similarities to SaniPath with the participatory approach drawing upon the community's knowledge of unsanitary situations or practices that may be the cause of health risks. However, the SaniPath requires the use of lab samples to estimate the level of risk whereas this study's methodology does not. Sanipath generates risk scores for exposure pathways and this study's methodology generates risk scores for hazardous events. The novel approach to risk scoring according to type of contaminated fluid used by this study could be incorporated into SaniPath in situations where there is not scope to use lab equipment. Similarly, the inclusion of a factor for vulnerability adds a dimension commonly used in risk assessment techniques that is not included in the SaniPath approach.

It is also different in that it does not have a pre-determined set of questions, it uses a participatory research approach to build up a unique set of questions. The benefit of this approach is that it does not risk generating misinformation as a result of a question that does not apply to the context. The flexibility of producing a unique question set allows the study to reveal more information that is specific to the local context. Furthermore, the use of context and system triggers, which is unique to this approach, builds a clear picture of why this system is failing and what can be done to improve it.

The development and application of the sanitary surveys proved to be an effective and flexible process for gathering information from a variety sources about the performance, condition and management of the sanitation infrastructure and FSM equipment and produced useful list of recommended interventions. However, the reliance on participatory research methods to develop the list of hazardous events may also fail to consider all hazards. For example, no hazardous events related to transport of sludge (e.g. leakage, accidents, unauthorised tipping, etc) were registered by any of the stakeholders (community residents, members of community 
based FSM group and civil servants were interviewed) consulted, but it is very likely that this isn't the case.

The reliance on a participatory approach to develop the list of hazardous events and question set is more dependent on the judgement and quality of the assessor and not as accessible to all levels of practitioner as rigid the step by step approach of the SaniPath and SFD. By following large question sets that require many site visits to assess the probability of all potential risks of faecal contamination the SaniPath and SFD approaches avoid this. This sanitary survey component of this study's methodology would benefit from a minimum list of site visits to be sure that omissions in the participatory process are discovered. The SFD methodology has a more robust system for verifying the quality and credibility of collected data; a similar process would benefit this study's methodology.

\section{Conclusions}

This study showed that a participatory approach that relies more on local input to capture information and does not involve a standard list of questions has benefits over existing methodologies for assessing faecal contamination in low-income settings as more context specific information can be revealed to the point that specific recommendations for improvements can be made.

It was also seen that this study's sanitary survey approach must involve more processes for stakeholder information verification (e.g. site visits) than was used in this study. The SFD approach to data verification could be of merit in all rapid, low cost faecal contamination assessment methodologies. Furthermore without the use of a standard set of questions the process is more subjective and therefore necessitates a more knowledgeable practitioner than SaniPath and SFD approaches.

The context specific and focussed nature of this methodology's sanitary survey approach has standalone value and could be used to complement both the SaniPath and SFD approaches to provide closer analysis of key systems and make recommendations. It could be used in its present form to complement the SFD approach, but would need to be modified to capture all the SaniPath exposure pathways.

\section{Acknowledgements}

This study was developed by the International Water Association (IWA) and funded by the European Water Initiative ERA-NET (SPLASH). The project partners involved were Class-A (Maputo based NGO for WASH) and University College London. Mr William Acker was funded by the UCL Chadwick Trust.

\section{References}


Ashbolt, N. Snozzi, G. (2001). Water Quality: Guidelines, Standards and Health. Chapter 13: Indicators of Microbial Water Quality. World Health Organization. Geneva, Switzerland.

Banerjee, G. Morella, E. (2011). Africa's water and sanitation infrastructure: Access, affordability and alternatives. The World Bank, Washington DC, USA.

Campos, L.C., Parkinson, J., Ross, P., Nasir, Z.A., Taylor, H. (2015). Development and application of a methodology to assess sanitary risks in Maputo, Mozambique Environment and Urbanization, 27(2):1-19

Crichton, D. (1999). Natural Disaster Management. Tudor Rose, London, UK.

Emory University (2014). Sanipath Rapid Assessment Tool Manual. Global Center for Safe Water. Atlanta, USA.

EPA (1980). Design manual: Onsite wastewater treatment and disposal systems. Washington D.C.: Office of Water Program Operations and Office of Research and Development Publication Number 625/1-80-012.

EPA. n.d. Water monitoring and assessment: 5.11 - Faecal bacteria. http://water.epa.gov/type/rsl/monitoring/vms511.cfm. Accessed on 30/06/16

Geldreich, E. Best, L. Kenner, B. Van Donsel, D. (1968). The Bacteriological Aspects of Stormwater Pollution. Water Pollution Control Federation 40 (11), Part I pp. 18611872

Godfrey, A. (2012). Faecal Sludge Management Demonstration Project in Maxaquene A and $B$. WSUP. London, UK.

Horsley and Witten Inc. (1996). Identification and evaluation of nutrient and bacterial loadings to Maquoit Bay, New Brunswick and Freeport, Maine. Casco Bay Estuary Project. Massachusetts, USA.

Lahmeyer Group (2004). Strategic plan for the 7 municipalities. Volume 2.7. Maputo, Mozambique

Muxímpua, O. Hawkins, P. (2012). Building blocks for effective faecal sludge management in peri-urban areas: the role of small-scale service providers in Maputo. The $2^{\text {nd }}$ International Fecal Sludge Management conference. Durban, South Africa.

SFD Promotion Initiative (2015). Manual for SFD Production. www.SFD.Susana.org Accessed on: $30 / 06 / 2016$

IWA (2011). Sustainable and resilient sanitation service chains in Maputo province, Mozambique: Action research and piloting for the benefit of the urban poor. Project Inception report. London, UK.

IWA (2014). Sustainable and resilient sanitation service chains in Maputo province, Mozambique: Action research and piloting for the benefit of the urban poor. Project Final Report. London, UK

WHO (2006). Meeting the MDG drinking water and sanitation target - the urban and rural challenge of the decade. World Health Organization, Geneva, Switzerland.

WSUP (2010). Formulation of an overall strategy for the municipal planning of sanitation in the city of Maputo. Final report. Maputo, Mozambique 